definite shapes and proportions of some of the great and longunknown reptilian masters of the world, whether dignified in their monstrous bulk and unused power, as Herbivores, or domineering as the Carnivorous tyrants of their day" (Geol. MAG. 1869, p. 566).

Hypsilophodon, Compsognathus, and Hallopus are the smallest - the first about four feet long, and the last "about the size of a fowl," and probably light enough to hop about. The larger forms, such as Iguanodon in Europe, and Claosaurus and others in America, reached about thirty feet in length and fifteen in erect height. These animals, (like Crocodiles) adapted for both swimming and walking, have left their tracks on former mud-flats and sand-banks, as in Sussex and Connecticut. In the latter district they are mingled with possible bird-tracks and probable labyrinthodont footprints.

Beginning with the Trias, they ended their career in the early part of the Cretaceons period; and they brought with them certain structural peculiarities, which became more developed and specialized in Birds. The Pterodactyle (flying reptile) and Archoopteryx (reptilian bird) present other such evidences of progressive stages among life-forms.

The "Ancient Birds" have Chap. viii. to themselves, bringing the reader through the Cretaceous period, with its toothed birds, to a few centuries and less ago when the Moa, Dodo, Solitaire, and Great Auk have succumbed to destructive Man.

Chapter ix. begins a new era of the history of the "Creatures of Other Days," with animals of the Tapir and Elephant types; those belonging to the Horse, Whale, and Wombat occupy Chapters x. and xi.; and some extinct South-American creatures, and the Californian $\mathrm{Ox}$, end the series in Chapter xii.

The most advanced and highest Mammals are doubtlessly shown in Plates $i$. and xii., though the latter is placed in the Dinosaur chapter ; for Richard Owen, Huxley, Marsh, Cope, von Zittel, and Gaudry, are here pourtrayed as representative palæontologists. The other numerous illustrations have also been carefully prepared, and in many cases are artistically good.

Certainly verbal errors (by author or printer) are not absent; and there are obscurely elliptical phrases, such as "the genus must have been as large as an ostricht" (p. 161). The author's own "kind friends" will probably have drawn his attention to some such weaknesses, and to points on which differences of opinion are held. We need only say that the book is clearly and pleasantly written; it is full of desirable information well considered and conveniently arranged.

T. R. J.

\title{
COREFSPONDEINCE.
}

\section{DYNAMICAL METAMORPHISM.}

SiR,-In connection with my friend Mr. Harker's remarks on experimental dynamic metamorphism, some of your readers may be interested to try for themselves on $\theta$ of the simplest cases. Apparatus-a teaspoon, a lamp, a sheet of paper, and a few crystals 
of Biniodide of Mercury. Heat the scarlet crystals in the teaspoon over the lamp; they become pale yellow. Place them on the paper, and rub them with the thumb-nail, and they become scarlet again. They are now reduced to a red powder colouring the paper. Pass the paper to and fro over the lamp, the scarlet instantly turns yellow. Attempt to rub the powder off by passing the paper over the carpet, the paper instantly turns red again.

Miller explains the change from yellow to red as follows:"Warrington has shown that this ehange of colour depends upon a change in the molecular constitution of the salt, in consequence of which the rhomboidal crystals are converted into octahedra with a square base." This alone would be sufficiently perplexing, but the changes seem capable of being produced over and over again, and we have simply to alternate thermal and dynamic metamorphic processes to produce the yellow biniodide and the scarlet biniodide of mercury at pleasure. If these things may be done in the drawing-room, what may not thermal and dynamic metamorphism, alone or combined, effect in the laboratory of nature?

One more possible case. In using the soldering iron (which iron. is always copper) a very moderate temperature is essential to keep the solder on the face of the clean copper, a temperature far below that requisite to melt copper with tin to produce one of the coppertin alloys; yet occasionally the soldering iron will show streaks of yellow gun-metal. An amateur in his attempts at soldering is apt to press the soldering iron heavily on his work, and it seems possible that the alloy indicated on the iron may arise from insufficient heat being reinforced by equally insufficient pressure; the two combined being, however, sufficient to produce an alloy of copper and tin. If this be so we have in the soldering iron a case of thermal and dynamic metamorphism in combination, just as in the biniodide of mercury we have thermal and dynamio metamorphism in alternation.

A friend employed on the Manchester Ship Canal once sent me a specimen of red sandstone from a slickenside. At the plane of contact and pressure the red colour is entirely discharged, and the stone apparently porcellanized. The depth to which the metamorphic action extends is so very slight, sometimes less than $\frac{1}{8}$ th of an inch, that the metamorphosis would seem due to pressure rather than heat, as it is difficult to understand how pure thermal action could be restricted to such a mere film.

Torquay, 16th June, 1894.

\section{A. R. HUnT.}

\section{SHELLS FROM PORTLAND RUBBLE DRIFT.}

SrR,-I had the pleasure of several hours work in June last at the Rubble Drift at Portland, both at Chesilton and at the Bill.

I was not able to obtain any recent shells from the Chesilton Rubble; but I would remark on the enormous angular and subangular blocks of Portland oolite that occur in this section at various horizons, the whole of the material being unsorted, and therefore having been accumulated by more or less rapid aggregation of material in a comparatively brief space of time. 